\title{
How to Travel After the COVID-19 Pandemic?
}

\author{
Peter P. Felkai ${ }^{*}$ \\ ${ }^{1}$ SOS Hungary Medical Assistance Service, Budapest, Hungary
}

Corresponding Author: Peter P. Felkai, MD, PhD, Associate Professor, SOS Hungary Medical Assistance Service, Szentendrei út 301, Budapest, Hungary. Tel: +36-1-2400475, Email: peter.felkai@soshungary.hu

Received July 1, 2020; Accepted September 29, 2020; Online Published November 14, 2020

\begin{abstract}
As countries worldwide are beginning to end their lockdowns due to the coronavirus disease 2019 (COVID-19) pandemic, travel and tourism are again becoming possible. However, pre-pandemic travel practices are not likely to resume for some time, at least until a COVID-19 vaccine becomes available. The current time is a crucial one that requires us to reconsider our strategies to protect health and prevent travel-related diseases. This article therefore addresses various considerations for the resumption of tourist activities and the near future of travel, such as pre-travel medical counseling, personal hygiene, luggage handling, food safety, and measures to ensure safety on airplanes and in hotels. These considerations may aid in delineating a way forward for the travel industry and for travelers alike. Author believes that this article is especially timely and of interest not only for travel medicine specialists but all participants in the field of travel business.
\end{abstract}

Keywords: Travel Medicine, Pretravel Consultation, Air Travel, Coronavirus, Prevention, Vaccination

Citation: Felkai PP. How to travel after the COVID-19 pandemic? Int J Travel Med Glob Health. 2021;9(1):1-3. doi:10.34172/ijtmgh.2021.01.

\section{Introduction}

The nightmare of lockdown is slowly coming to an end: borders are reopening, travel agencies are offering trips again, hotel rooms can be reserved, restaurants can reopen, and attractions can be visited again. The tourism industry and the countries relying on tourism may be saved. After the pandemic, people are likely to feel a renewed desire for adventure travel, exploring nature and enjoying the most popular way to spend leisure time: traveling.

However, traveling will not be the same as it was before the pandemic. We have recently been reminded of the previously forgotten tough lesson that contagious disease spread is a consequence of mass movement, such as that by the military, merchants, pilgrims or crowds of tourists. This movement can be disastrous. For example, the Great Plague of 1935, which killed half the population of Europe at the time, took 8 years to travel from Asia to Western Europe, whereas the coronavirus disease 2019 (COVID-19) pandemic traveled across the world in less than 24 hours. Modern transport systems carry large numbers of people over vast distances during very short durations, and this speed has enabled the pandemic's rapid worldwide spread. Consequently, the breakout of a new pandemic may be possible for years to come. Meanwhile tourism has reached new volumes, with luxury ships carrying 6000 passengers and planes carrying
850 passengers, thus, resulting in "tourist invasions" that have caused Venice, Prague or Barcelona to use signs reading "jampacked". The COVID-19 pandemic has occurred against this backdrop.

Current travel practices will certainly not be sustained. Of course, being unable to see the cultural riches of foreign countries, or enjoying recreation during a seashore vacation or active relaxation through recreational sports would be a pity. Therefore, we must reconsider our strategies to protect our health to prevent travel-related diseases.

The first thing that most travelers tend to ignore before international travel is pre-travel medical counseling and vaccination. ${ }^{1,2}$ After the COVID-19 pandemic, such practices will be is vital for older people, because of the possibility of multiple co morbidities in this sensitive population. ${ }^{3,4}$ The same is true for children. Vaccine recommendations should be taken seriously before travel to endemic areas, and safety measures should be taken to prevent malaria.

Viruses that spread by aerosol droplets are expelled from affected people's airways during coughing or sneezing, and spread not only through entering the airways of healthy people but also through surfaces, thus making spread via touching possible. Therefore, washing the hands frequently decreases the adhesion of virulent agents to the hands. Scientific experiments have demonstrated that washing the

Copyright $(\odot 2021$ The Author(s). This is an open-access article distributed under the terms of the Creative Commons Attribution License (http:// creativecommons.org/licenses/by/4.0), which permits unrestricted use, distribution, and reproduction in any medium, provided the original work is properly cited. 
hands with soap is much more efficient than using alcoholbased sanitizers. ${ }^{5}$ Hand washing with plain soap prevents most illnesses and decreases contamination with agents causing digestive system diseases by $20 \%-40 \%{ }^{6}$

Another frequently neglected aspect of traveling abroadespecially in tropical countries-is the safe consumption of water and food. Half of the diseases that can be contracted during travel are caused by eating or drinking contaminated or non-habitually consumed food, or by drinking contaminated water. Although viruses may not be detected in drinking water or properly treated food, ${ }^{7}$ food purchased from street vendors, and drinks that are not factory packaged and sealed, may be dangerous. People whose immune systems are already weakened by other digestive diseases are particularly sensitive to bacterial or viral infections. Therefore, the rules of "cook it, boil it, peel it, or if none of the above is possible, forget it" are especially important in tropical countries.

The self-handling and packing of luggage decreases the risk of contact infection and the use of already available ultraviolet light disinfection lamps can further increase the level of protection. ${ }^{8}$ Of course, it would be ideal for airports to also use this method for package handling. Disinfection and cleaning in hotel rooms will be performed with greater care after the epidemic has subsided, and further disinfecting the bathroom and the area around the beds does no harm.

According to experts from the International Air Transport Association, domestic flights may return to old practices as early as July 1, 2020, whereas a full resumption of international flights is predicted for October of 2020. ${ }^{9}$ Airlines must also alter their previous fuel-saving policies: instead of the current $50 \%$ cabin air exchange, the entire cabin air should be replaced regularly. The cabin ventilation system can promote the spreading of gems and by that some kind of upper respiratory infections - most often the flu and cold. ${ }^{10}$ Epidemiological studies of SARS have shown that passengers closely seated to each other can transmit infection among themselves. ${ }^{11,12}$ This finding prompts the question of how far apart passengers should sit. No studies have determined the exact range necessary for so-called "social distancing" (recommendations range from 1 to 8 meters ${ }^{12,13}$ ), but passengers crowded into the 10 seats of an economy class row can certainly transmit any respiratory infection among themselves at any time. Research and regulations regarding wearing protective masks are contradictory, ${ }^{14,15}$ but because COVID-19 is transmitted by droplet infection, masks are clearly worth wearing for individual protection, particularly in crowded environments such as public transport or economy class aircraft. Increasing the distance between seats is also recommended to prevent travel thrombosis. Clearly, on-board meals will also be limited by these measures, and the cost savings on catering could potentially cover the financial loss due to less dense setting. The practice of placing bottles of disinfectants at the entrances to hotel ships was introduced during greater rotavirus outbreaks: this solution may also be an option for people to use before boarding an aircraft.

There is another important issue which should be mentioned during pretravel consultation: to have appropriate travel insurance. Besides of the increased risk of the COVID threatening, the travel restrictions which can vary every minute. Then the insurance covering good for not only for medical reasons but the cancellation of the trip or the extra expenses due to the possible quarantine of the traveler.

\section{Conclusion}

The current time is a crucial one that requires us to reconsider our strategies to protect health and prevent travel-related diseases, as well as the travel practices. This article therefore addresses various considerations for the resumption of tourist activities and the near future of travel, such as pre-travel medical counseling, personal hygiene, luggage handling, food safety, and measures to ensure safety on airplanes and in hotels. These considerations may aid in delineating a way forward for the travel industry and for travelers alike. The solution will ultimately require coronavirus vaccination, but before then, it would be inappropriate to restrict travel or make international traffic difficult. Several basic infection control and public health facts should be directly translated into action and authentic, honest information must be first given to the public in a timely manner.

\section{Conflict of Interest Disclosures}

Peter P. Felkai serves as a editorial board of International Journal of Travel Medicine and Global Health.

\section{Ethical Approval}

Not applicable.

\section{Funding/Support}

None.

\section{References}

1. Hamer DH, Connor BA. Travel health knowledge, attitudes and practices among United States travelers. J Travel Med. 2004; 11(1):23-26. doi:10.2310/7060.2004.13577.

2. Lengyel I, Felkai P. [Pre-travel advice and patient education of Hungarian travellers]. Orv Hetil. 2018;159(9):357-362. doi:10.1556/650.2018.30987.

3. Kang SJ, Jung SI. Age-related morbidity and mortality among patients with COVID-19. Infect Chemother. 2020;52(2):154-164. doi:10.3947/ic.2020.52.2.154.

4. Reichert T, Chowell G, McCullers JA. The age distribution of mortality due to influenza: pandemic and peri-pandemic. BMC Med. 2012;10:162. doi:10.1186/1741-7015-10-162.

5. Tuladhar E, Hazeleger WC, Koopmans $M$, Zwietering $\mathrm{MH}$, Duizer E, Beumer RR. Reducing viral contamination from finger pads: handwashing is more effective than alcohol-based hand disinfectants. J Hosp Infect. 2015;90(3):226-234. doi:10.1016/j. jhin.2015.02.019.

6. Luby SP, Agboatwalla M, Feikin DR, et al. Effect of handwashing on child health: a randomised controlled trial. Lancet. 2005;366(9481):225-233. doi:10.1016/s0140-6736(05)66912-7.

7. Centers for Disease Control and Prevention (CDC). Food and Coronavirus Disease 2019 (COVID-19). https://www.cdc.gov/ coronavirus/2019-ncov/daily-life-coping/food-and-COVID-19. html. Accessed June 23, 2020

8. Ragan I, Hartson L, Pidcoke H, Bowen R, Goodrich R. Pathogen reduction of SARS-CoV-2 virus in plasma and whole blood using riboflavin and UV light. PLoS One. 2020;15(5):e0233947. doi:10.1371/journal.pone.0233947. 
9. International Air Transport Association (IATA). IATA Updates COVID-19 Financial Impacts -Relief Measures Needed. https:// www.iata.org/en/pressroom/pr/2020-03-05-01. Accessed June 23, 2020.

10. Saleri N, Ryan ET. Respiratory infections. In: Travel Medicine. $4^{\text {th }}$ ed. Elsevier; 2019:527-537. doi:10.1016/B978-0-323-546966.00059-8.

11. Smith RD. Responding to global infectious disease outbreaks: lessons from SARS on the role of risk perception, communication and management. Soc Sci Med. 2006;63(12):3113-3123. doi:10.1016/j.socscimed.2006.08.004.

12. Olsen SJ, Chang HL, Cheung TY, et al. Transmission of the severe acute respiratory syndrome on aircraft. N Engl J Med. 2003;
349(25):2416-2422. doi:10.1056/NEJMoa031349.

13. World Health Organization (WHO). Coronavirus Disease (COVID-19) Advice for the Public. https://www.who.int/ emergencies/diseases/novel-coronavirus-2019/advice-for-public. Accessed June 23, 2020.

14. Bourouiba L. Turbulent gas clouds and respiratory pathogen emissions: potential implications for reducing transmission of COVID-19. JAMA. 2020;323(18):1837-1838. doi:10.1001/ jama.2020.4756.

15. Ma QX, Shan H, Zhang HL, Li GM, Yang RM, Chen JM. Potential utilities of mask-wearing and instant hand hygiene for fighting SARS-CoV-2. J Med Virol. 2020. doi:10.1002/jmv.25805. 